\title{
The hormetic functions of Wnt pathways in tubular injury
}

\author{
Elisabeth F. Gröne ${ }^{1}$ • Giuseppina Federico ${ }^{1} \cdot$ Peter J. Nelson $^{2}$ • Bernd Arnold ${ }^{1}$ • \\ Hermann-Josef Gröne ${ }^{1}$
}

Received: 9 May 2017 / Revised: 13 June 2017 / Accepted: 13 June 2017 / Published online: 6 July 2017

(C) The Author(s) 2017. This article is an open access publication

\begin{abstract}
Chronic tubulointerstitial damage with tubular epithelial atrophy and interstitial fibrosis is the hallmark of chronic kidney disease (CKD) and a predictor for progression of CKD.

Several experiments have now provided evidence that the Wnt signaling pathways are significantly contributing to atrophy and fibrosis; in contrast, it also has been shown that the Wnt system fosters regenerative processes in acute tubular injury.

We now have demonstrated that Dickkopf 3 (DKK3) is an agonist for canonical Wnt signaling in CKD and fosters chronic fibrosing inflammation of the tubulointerstitial compartment. Genetic- and antibody-mediated inhibition of DKK3 leads to a pronounced improvement of tubular differentiation and a reduction in fibrosis.

In addition, the secreted glycoprotein DKK3 can be used as a non-invasive urinary marker for the extent of CKD in man.
\end{abstract}

Keywords Wnt pathways $\cdot$ Dkk3 $\cdot$ Fibrosis $\cdot$ Atrophy

This article is part of the special issue on Functional Anatomy of the Kidney in Health and Disease in Pflügers Archiv_-European Journal of Physiology

Hermann-Josef Gröne

h.-j.groene@dkfz.de; h.-j.groene@dkfz-heidelberg.de

1 Department of Cellular and Molecular Pathology, German Cancer Research Center (DKFZ), Im Neuenheimer Feld 280, 69120 Heidelberg, Germany

2 Clinical Biochemistry, Ludwig Maximilian University, Munich, Bavaria, Germany

\section{Definition of acute and chronic tubular injury in the study of Wnts}

As the effects of Wnt pathways in tubular injury will be discussed, these actions should be put into context of the quality and extent of epithelial injury which may be species-specific and may not necessarily reflect the pathohistology and pathophysiology of acute and chronic renal tubulointerstitial diseases seen in man.

In man, acute injury of tubular epithelia can be characterized by morphologic, biochemical, and functional means. In proximal tubules, lesions can vary from slight cytoplasmic vacuolization and a change in brush border height to cell death. Different degrees of loss of cell polarity and differentiation can be associated with emergence of embryonal gene and protein patterns. Exemplarily, vimentin - by convention assumed to be a mesenchymal cytoskeletal protein marker - can be observed temporarily. Once the causative factor ceases to exert its influence on injured epithelia, a regenerative process occurs which may lead to a "restitutio ad integrum", but can also result in focal chronic atrophic and fibrotic areas of the tubulointerstitium of the cortex and the outer medulla. Cells and matrix surrounding the tubules exert a significant influence on the extent of injury and its recovery. Tubulointerstitial crosstalk is a term to describe the interaction between tubular epithelia and interstitial cells although it obfuscates the lack of knowledge of this process. There can be major differences between rodent models of acute tubular injury and the morphology of acute epithelial lesions seen in human renal biopsies.

In acute renal failure in humans, tubular epithelial injury often occurs without significant inflammatory mononuclear cell infiltrate in the interstitium and without necrosis/ 
apoptosis of the epithelia. In contrast, in mice, neutrophilic granulocytes populate the peritubular capillaries and the interstitium in acute hypoxic injury.

In order to achieve analogies between mouse and man, animal models may be taken akin to the morphology of acute tubular injury in man.

In chronic tubular injury, generally accepted morphologic features have not been defined to which extent an epithelium has to show broadened basement membranes, loss of polarity, and "dedifferentiation" to be irreversibly damaged and termed "atrophic" and "atretic". The epithelial changes may take place in conjunction with an increase in interstitial matrix or fibrosis. Interstitial fibrosis is thought to be mainly generated by the interstitial myofibroblasts - influenced by fibrogenic cytokines, secreted by tubular epithelia and microvascular endothelia. In diabetic nephropathy though, as well as in other chronic glomerular diseases, degenerating tubules may demonstrate massively broadened basement membranes which can coalesce and contribute significantly to the buildup of interstitial extracellular matrix (Fig. 1). In contrast to the usual association of tubular atrophy and tubulointerstitial fibrosis, chronic tubular injury may develop without a relevant interstitial matrix increase in cases of selectively decreased perfusion, pressure, and glomerular filtration resulting in "inactivity atrophy" of tubules, which often is reversible after restoration of glomerular filtrate. Some animal models may not mirror the slowly progressing tubular degeneration observed in man. As an example of a misguided animal experiment, "damage and interstitial fibrosis" has been studied 5 to 7 days after unilateral ureter obstruction when chronic tubular injury has not yet developed, and interstitial fibrosis - which is not the main characteristic of this model — can hardly be seen.

\section{Wnt pathways}

Wnt is a conjugation of two terms: $\mathrm{Wg}$, meaning wingless, and Int. Mutation of the wingless gene leads to flies without

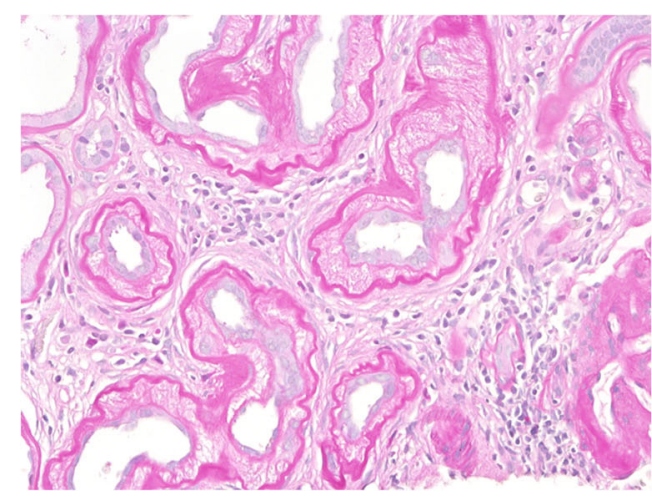

Fig. 1 Two significantly different types of interstitial fibrosis and tubular atrophy are shown in human renal biopsies. In the left photograph, tubular cells contribute to extracellular matrix increase by a dramatic broadening of the tubular basement membrane. In the right photograph, tubular wings. The Int1 gene enhances breast carcinoma development in mice when the mouse mammary tumor virus (MMTV) integrates into the vicinity of the Int 1 gene $[2,3]$.

There are $19 \mathrm{Wnt}$ ligands $(\mathrm{MW} \approx 40 \mathrm{kDA}$ ) binding either to a heterodimeric complex of lipoprotein receptor related protein 5 or 6 (LRPP 5 or 6 ) and a member of a seven transmembrane protein Frizzled (Fz)-family with 10 receptor proteins or to receptor tyrosine kinase-like orphan receptor (ROR) or to a receptor-like-tyrosine kinase (Ryk) [5, 7, 12, 26, 32, 38, 39].

The binding of a Wnt to a receptor depends on acylation of Wnt by action of porcupine enzyme and CoA-palmitoleic acid [21, 28, 49]. LRP 5, 6 /Fz can lead to canonical pathway activity with binding of $\beta$-catenin to the transcription factors $\mathrm{TCF} / \mathrm{LEF}$ displacing the coinhibitor Groucho [1]. Some target genes are Axin 2, Dickkopf (DKK) 1 and 2, Wnt1-inducible signaling pathway proteins (WISPs), and secreted Frizzledrelated proteins (sFRP).

Specific Wnt ligands preferentially lead to activation of the calcium pathway with increased activity of phospholipase $\mathrm{C}$, calcineurin phosphatase, calcium/calmodulindependent kinase II (Cam kinase II), protein kinase C, and NFAT transcription factor $[2,3,15]$. In some epithelia, the planar cell polarity (PCP) pathway is activated either by $\mathrm{Wnt}$ binding to LRP/Fz or ROR with ensuing activity of Rho and JNK [14].

Multiple factors - some in the plasma membrane, some soluble — can potently activate or inhibit Wnt signaling [12, 22, 49].

In addition to concentration of the ligands/coactivators/ coinhibitors, time of activity in a physiologic or pathophysiologic process, duration of activity, and crosstalk with other cytokine triggered pathways are influencing signaling. Also in the kidney, the Wnt pathways are a hormetic system, the effects of which are dramatically different in acute versus chronic tubular epithelial injury models [14, 36, 49]. In order to gain an overview of the effects of Wnt and associated proteins in acute tubular injury versus chronic tubular injury Table 1 lists published data.

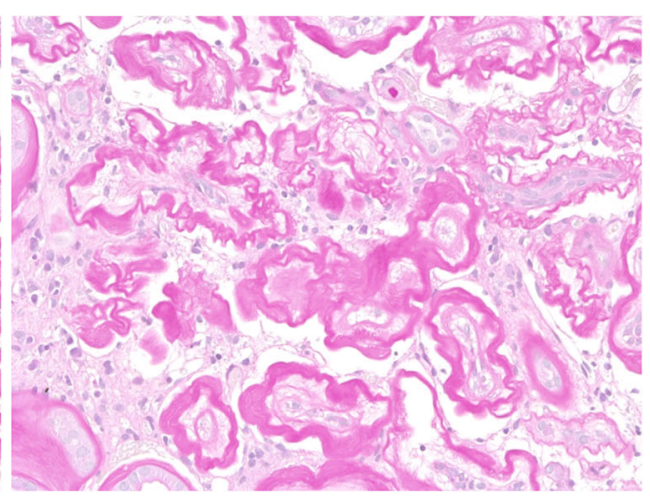

epithelial atresia with skeleta of tubules is surrounded by interstitial matrix produced by interstitial myofibroblasts. Lesions depicted to the left of Fig. 1 are not seen in mouse, and lesions as seen to the right are seldom observed in mouse (stain: PAS, magnification: 200x) 


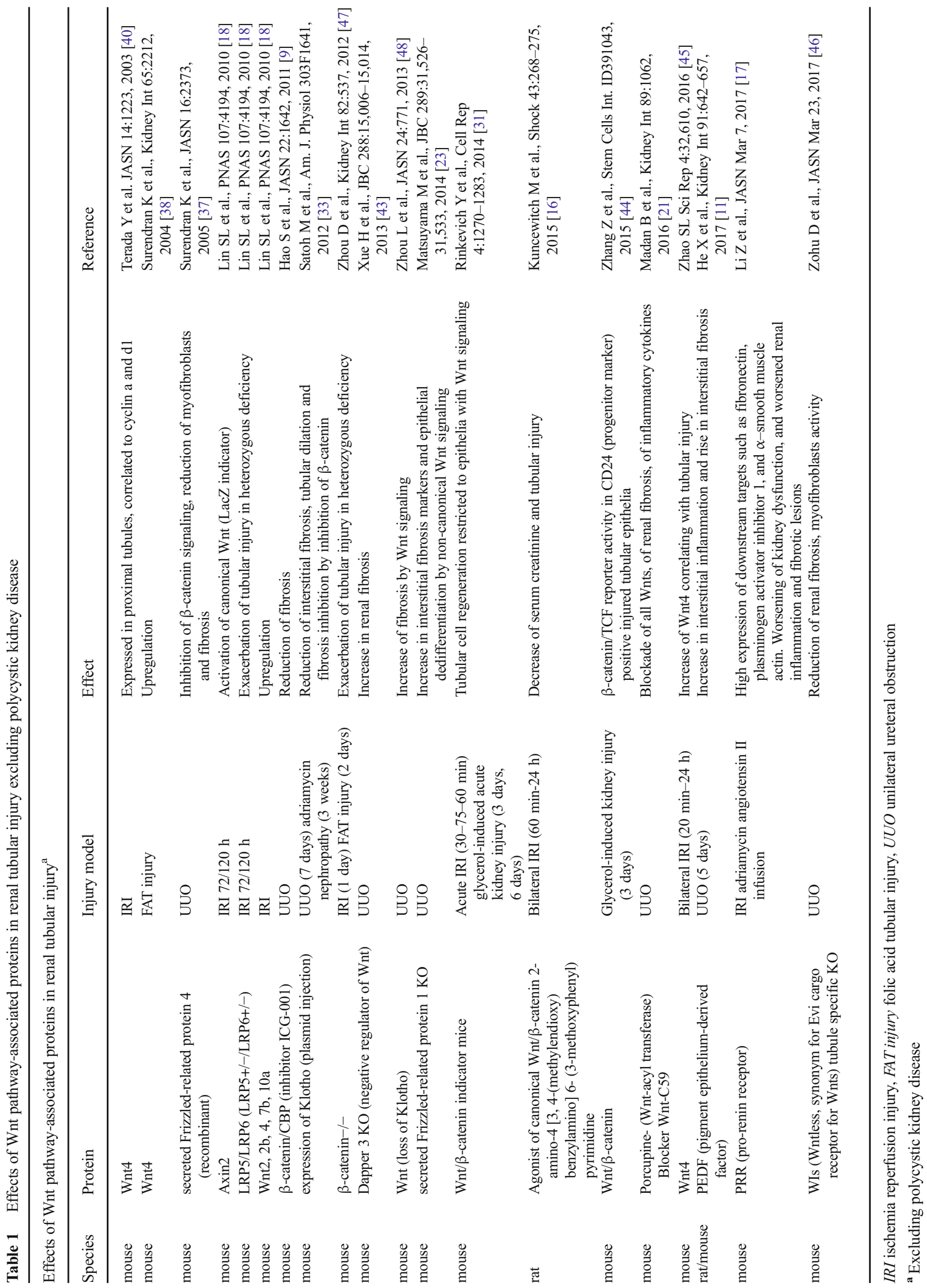


It is apparent that Wnt-associated proteins exert relevant effects, perhaps due to their actions independent of a single Wnt in contrast to the selective action of a specific Wnt.

\section{Dickkopf 3 (DKK3)}

We have focused on the DKK family which can inhibit or activate Wnt pathways, dependent on the microenvironment $[8,22$, $27,35,42]$. One protein out of this family of Wnt-associated proteins, namely DKK3, synthesized by stressed tubular epithelia, has recently been shown by us to significantly modulate chronic tubulointerstitial injury and be of use as a non-invasive urinary marker for chronic tubulointerstitial lesions [6].

The DKK3 family consists of five proteins: DKK1, 2, 3, 4, and a DKK-like protein 1 (DKKL1, also known by the synonym Soggy) which is constitutively expressed in immuneprivileged organs in adult mammals, such as the testis, eye, and brain, but not in the adult kidney [6, 27]. DKK 1-4 share two conserved cysteine-rich domains (Cys). Cys1 is an Nterminal domain which is unique for DKKs, not found in other vertebrate proteins. The two Cys are separated by a linker region of variable length which is similar in DKK1, 2, 4, but small in DKK3 with only 13 amino acids.

Studies on DKK1 have demonstrated that DKK1 binds LRPs and inhibits Wnt signaling. DKK2 may have agonistic as well as antagonistic effects on Wnt pathways. Published effects of DKKs on the kidney are summarized in Table 2.

DKK3 has different effects as compared to the DKK1, 2, and 4. DKK3 is strongly expressed in mesenchymal progenitor and mesenchymal cells in vitro; it also exerts potent immunosuppressive effects $[20,24,29]$. We have shown that a deficiency of DKK3 led to an exacerbation and significant prolongation of experimental autoimmune encephalitis [29].

Based on our immunologic studies with DKK3 in the skin, brain, and the lymphopoietic system, we have postulated that DKK3 might demonstrate immunosuppressive and fibrogenic actions in chronic renal disease.

For the studies on the effects of DKK3 in CKD, two models of chronic tubular and interstitial damage were chosen to demonstrate the chronic renal effects of DKK3:

1. The unilateral ureter obstruction (UUO) model with a primary biophysical or mechanical impact for a maximum of 21 days and

2. The tubular toxicity driven model of chronic oral administration of adenine for a maximum of 28 days

In both models, a systemic knockout of DKK3 lessened tubular dedifferentiation and interstitial matrix increase (Fig. 2). This may seem surprising as in adult mice DKK3 has not been detected in the kidneys as documented by the DKK3-promoter-driven enhanced green fluorescence protein (eGFP) transgene mouse. In injured tubular epithelia though, DKK3 was demonstrated. Our starting hypothesis had been that as DKK3 is expressed during development it shall be reexpressed in pathophysiologic processes due to a hitherto unexplained general mechanism by which an embryonal pattern can be re-expressed at least partially in pathologic processes.

In order to provide evidence for the major DKK3 synthesizing cell, we have taken different approaches. A tubular and collecting duct epithelia-specific DKK3-deficiency-

Table 2 Effect of DKK-proteins in acute and chronic renal tubular injury

Effect of DKK-proteins in acute and chronic renal tubular injury

\begin{tabular}{|c|c|c|c|c|}
\hline Species & Protein & Injury model & Effect & Reference \\
\hline mouse & DKK1 recombinant & UUO 7-14 days & $\begin{array}{l}\text { Reduction of cMyc, twist, collagen, } \\
\text { fibronectin, fibrosis }\end{array}$ & $\begin{array}{l}\text { He W et al., JASN } \\
\text { 20:765-766, } 2009 \text { [10] }\end{array}$ \\
\hline mouse & $\begin{array}{l}\text { Recombinant } \mathrm{C} 2 \text { cysteine-rich } \\
\text { domain of } \mathrm{DKK} 2 \text { infused }\end{array}$ & $\begin{array}{l}\text { Bilateral IRI (infusion starts } \\
\text { at day } 0 \text { or } 1 \text { ) }\end{array}$ & $\begin{array}{l}\text { Tubular regeneration and faster fall } \\
\text { of serum creatinine }\end{array}$ & $\begin{array}{l}\text { Lin SL, PNAS } \\
\quad 107: 4194-4199,2010[18]\end{array}$ \\
\hline human & $\begin{array}{l}\text { SNPs of DKK3 and mRNA } \\
\text { DKK } 3\end{array}$ & $\begin{array}{l}\text { Adult polycystic kidney } \\
\text { disease (ADPKD) }\end{array}$ & Association with large cysts & $\begin{array}{l}\text { Liu M et al., JASN } \\
\text { 21:1510-1520, } 2010 \text { [19] }\end{array}$ \\
\hline mouse & $\begin{array}{l}\text { DKK1 AAV-increased } \\
\text { circulating DKK1 }\end{array}$ & UUO 4 days/unilateral IRI & $\begin{array}{l}\text { DKK1 binding to LRP6 blocking } \\
\text { PDGFBB pathway inhibiting } \\
\text { inflammation, fibrosis }\end{array}$ & $\begin{array}{l}\text { Ren S et al., PNAS } \\
\quad 110: 1440-1445,2013[30]\end{array}$ \\
\hline mouse/human & DKK3 deficiency & $\begin{array}{l}\text { UUO } 21 \text { days/adenine } \\
\text { nephropathy } 28 \text { days/ } \\
\text { human urine }\end{array}$ & $\begin{array}{l}\text { General and tubular specific DKK3 } \\
\text { deficiency with reduction of tubular } \\
\text { epithelial dedifferentiation and decrease } \\
\text { of fibrosis. In man, DKK3 in urine: } \\
\text { marker of extent of tubular atrophy } \\
\text { and fibrosis }\end{array}$ & $\begin{array}{l}\text { Federico G et al., JCI Insight } \\
\text { 1:e84916, } 2016 \text { [6] }\end{array}$ \\
\hline mouse & DKK1 recombinant & UUO & Inflammation, fibrosis downregulated & $\begin{array}{c}\text { Johnson BG et al., JASN } \\
6080826,2017 \text { [13] }\end{array}$ \\
\hline
\end{tabular}

IRI ischemia reperfusion injury, UUO unilateral ureteral obstruction 


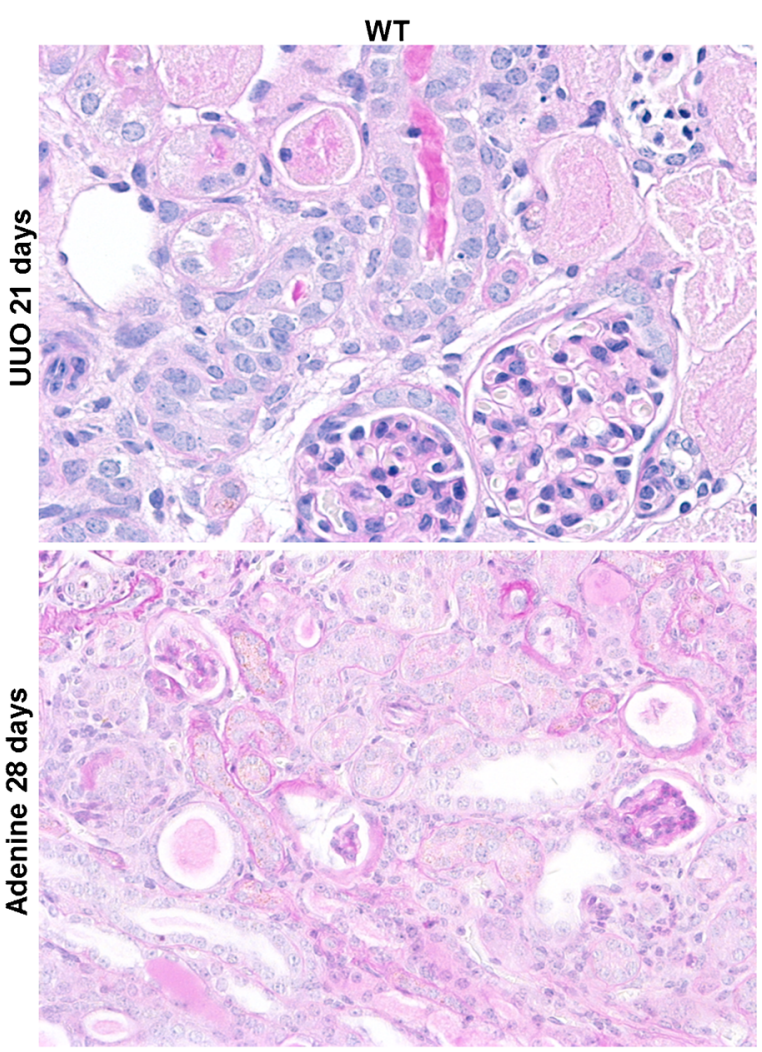

Fig. 2 DKK3-deficiency (graphs to the right) preserves tubular epithelial differentiation and reduces interstitial fibrosis in two different chronic models of tubulointerstitial fibrosis: UUO (unilateral ureter obstruction)

achieved by crossbreeding Pax8-Cre mice to a mouse line with a floxed DKK3 gene - also led to a pronounced preservation of renal parenchyma in both, the mechanical as well as the toxic model. This approach has provided evidence that DKK3-deficiency in tubular epithelia impeded tubular atrophy. This result has not been expected as regenerating cells have been associated with an active Wnt pathway, perhaps even taking place in differentiated cells [31,41]. Injection of pure $\mathrm{T}$ cells from wild-type mice and DKK3-systemically deficient mice into T cell-deficient Rag2 mice caused an increase in chronic tubulointerstitial injury in UUO to a similar degree as observed in wild-type mice, excluding T cells as the DKK3 synthesizing cell population for the prevention of chronic tubulointerstitial injury in DKK3 deficiency. Genetic approaches may have the drawback of induction of compensatory genetic mechanisms. Therefore, we have applied a long lasting blockade of DKK3 by repetitive injection of a functionally antagonistic DKK3 antibody. A significant reduction of tubular lesions and interstitial fibrosis could be observed by DKK3-antibody therapy [6].

The cell-molecular sequence interrupted or at least partially impeded by DKK3 inhibition has been analyzed by RNA-next generation sequencing, T cell transcription factors (GATA3 and Tbet), and cytokine measurements. The Th2 response in wild-type mice with UUO switched to a Th1 T cell activity

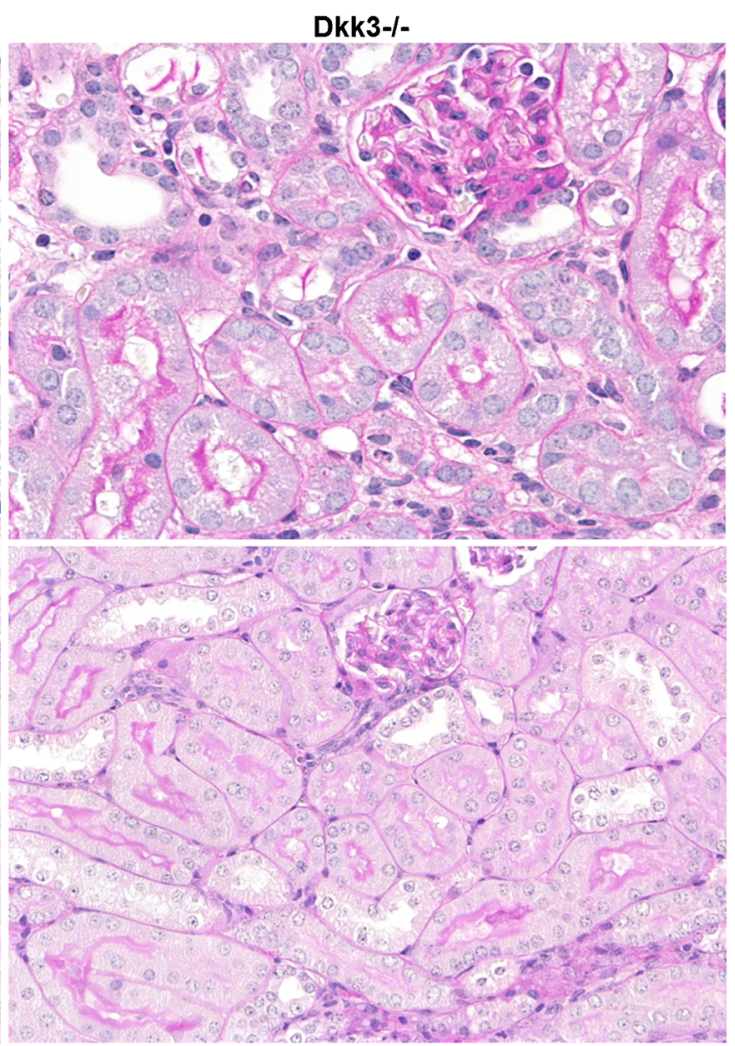

and adenine nephropathy (stain: PAS, magnification: 200x; male C57B1/6 mice 8 to 12 weeksold were used; adenine was administered in food at a concentration of $0.25 \%$ )

with an increase in IL1 $\beta, \operatorname{IFN} \gamma$, and TNF $\alpha$. Specifically elevated INF $\gamma$ concentrations have been associated with a suppression of increased matrix production; one potential mechanism is the repressive action of INF $\gamma$ on transcription of collagen genes. A regulatory component to this increased Th1 T cells was an increase in Foxp3 regulatory T cells infiltrating DKK3-deficient kidneys in higher quantities than in wild-type kidneys. These experiments also have established that a controlled "acute" inflammation might prevent chronic fibrosing lesions. In addition, experiments with indicator mice for the canonical Wnt pathway have suggested that DKK3 activates this Wnt signaling mode (Fig. 3). We have not been able to depict whether DKK3 - a secreted glycoprotein - induces tubular epithelia to secrete fibrogenic cytokines in an autocrine manner or whether DKK3 acts directly on T cells and/or interstitial fibroblasts to induce interstitial matrix deposition $[4,14,25,34]$.

The secretion of DKK3 has been used to evaluate chronic tubulointerstitial changes in mouse and man by measuring concentration and quantity of DKK3 in urine. We have determined urinary DKK3 concentrations in two different age groups: children/adolescents and adults, both with mixed etiologies of their chronic renal diseases. The urine DKK3 ELISAmeasurements have been correlated to morphometrically determined tubular atrophy and interstitial fibrosis in renal biopsies 


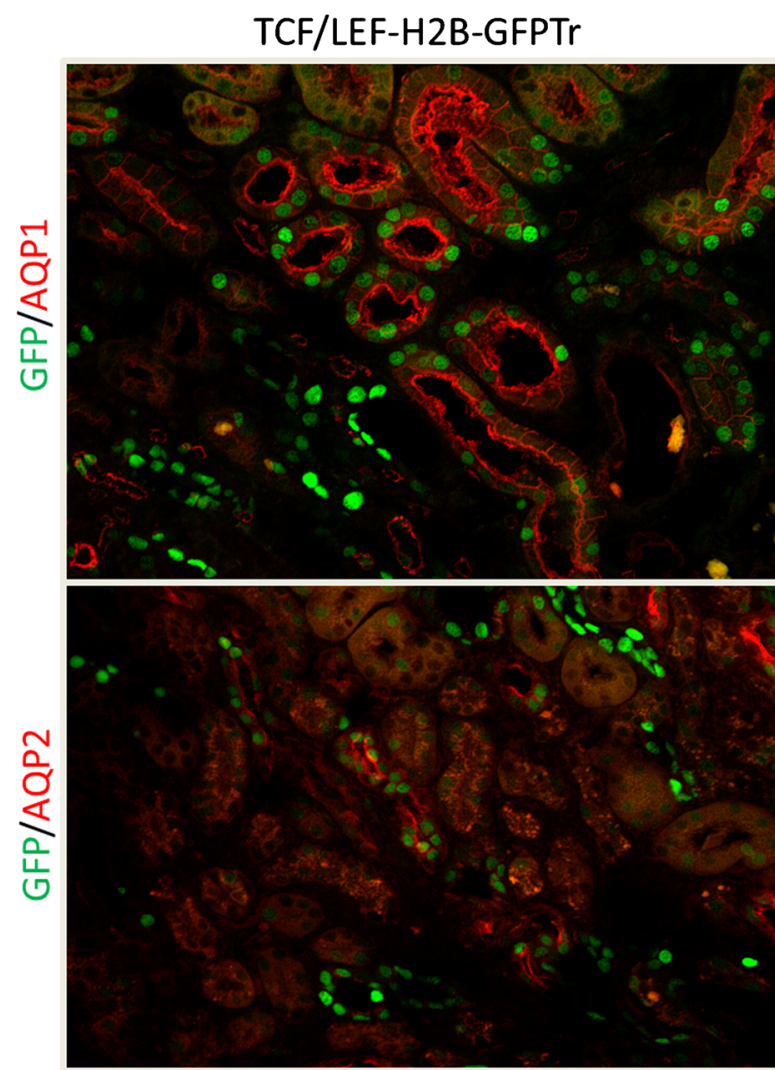

Fig. 3 "Canonical Wnt signaling" indicator mice demonstrate evident nuclear fluorescence in wild-type mice with UUO after 7 days; in contrast, DKK3 deficiency mice have a significant reduction in renal tubular epithelial fluorescence (AQP1: aquaporin 1 for proximal tubules, AQP2: aquaporin 2 for collecting ducts, TCF/LEF-H2B-

in the adult population and to proteinuria, plasma creatinine, and estimated GFR (e-GFR) in the pediatric and adult cohorts ranging in number from 32 (adult) to 72 (pediatric). There was no correlation to proteinuria. ROC (Receiver-OperatingCharacteristic) curve established a significantly higher correlation of the DKK3 values to tubular atrophy and to interstitial fibrosis - regarded as two separate entities - than of the serum creatinine concentration and e-GFR [6].

Although the clinical value of DKK3 urinary measurements for the determination of tubular atrophy and interstitial fibrosis has to be corroborated in larger and ethnically divergent patient cohorts, we are convinced that a non-invasive urinary biomarker for chronic tubulointerstitial damage, relating to prognosis and course of the chronic renal disease, has been detected.

In summary, there is ample evidence that the Wnt pathways play a decisive role in the regenerative or reparative processes after acute injury and in the progression of chronic tubular injury. Several issues remain unresolved:

1. Which factor (s) determine that Wnts act in a regenerative manner in acute tubular injury and in contrast act in a

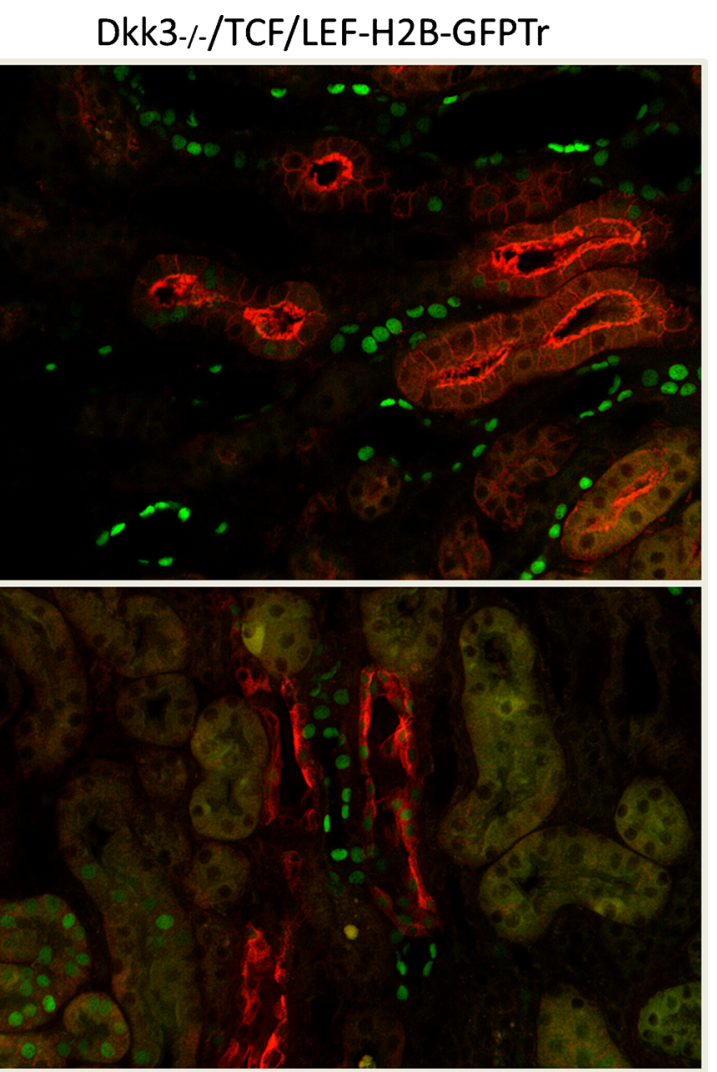

GFPTr: reporter mouse with expression of green fluorescent protein when promoter regions of the Wnt dependent transcription factors TCF/ LEF are activated by the canonical Wnt pathway. As nuclear fluorescence is evaluated unspecific background stain does not interfere)

perpetuating and exacerbating manner in chronic tubular injury?

2. Which Wnts and associated proteins and which Wnt pathways are dominant in acute and in chronic injury and may this depend on the kind of injury?

3. With which other pathways do Wnts interact or even exert their major action?

4. Do Wnt-associated proteins solely act by Wnt or do they exhibit multivalency? LRPs can interact with other pathways $[14,32]$.

5. Which is (are) the interacting protein (s), lipid (s), or receptor(s) for some of the Wnt-associated proteins? (e.g., for DKK3 neither a receptor nor a direct interacting protein has been unambiguously detected).

Open Access This article is distributed under the terms of the Creative Commons Attribution 4.0 International License (http:// creativecommons.org/licenses/by/4.0/), which permits unrestricted use, distribution, and reproduction in any medium, provided you give appropriate credit to the original author(s) and the source, provide a link to the Creative Commons license, and indicate if changes were made. 


\section{References}

1. Behrens J, von Kries JP, Kühl M, Bruhn L, Wedlich D, Grosschedl R, Birchmeier W (1996 Aug 15) Functional interaction of betacatenin with the transcription factor LEF-1. Nature 382(6592): 638-642

2. Clevers H, Loh KM, Nusse R (2014) Stem cell signaling: an integral program for tissue renewal and regeneration: Wnt signaling and stem cell control. Science 346(6205): 1248012

3. Clevers H, Nusse R (2012) Wnt/ $\beta$-catenin signaling and disease. Cell 149(6):1192-1205. doi:10.1016/j.cell.2012.05.012 Review

4. Das A, Tanigawa S, Karner CM, Xin M, Lum L, Chen C, Olson EN, Perantoni AO, Carroll TJ (2013) Stromal-epithelial crosstalk regulates kidney progenitor cell differentiation. Nat Cell Biol 15(9): 1035-1044. doi:10.1038/ncb2828 Erratum in: Nat Cell Biol. 2013 Oct; 15 (10):1260

5. Edeling M, Ragi G, Huang S, Pavenstädt H, Susztak K (2016) Developmental signalling pathways in renal fibrosis: the roles of Notch, Wnt and Hedgehog. Nat Rev Nephrol 12(7):426-439

6. Federico G, Meister M, Mathow D, Heine GH, Moldenhauer G, Popovic ZV, Nordström V, Kopp-Schneider A, Hielscher T, Nelson PJ, Schaefer F, Porubsky S, Fliser D, Arnold B, Gröne HJ (2016) Tubular Dickkopf-3 promotes the development of renal atrophy and fibrosis. JCI Insight 1(1):e84916

7. Fradkin LG, Dura JM, Noordermeer JN (2010) Ryks: new partners for Wnts in the developing and regenerating nervous system. Trends Neurosci 33(2):84-92. doi:10.1016/j.tins.2009.11.005 Review

8. Glinka A, Wu W, Delius H, Monaghan AP, Blumenstock C, Niehrs C (1998) Dickkopf-1 is a member of a new family of secreted proteins and functions in head induction. Nature 391(6665):357362

9. Hao S, He W, Li Y, Ding H, Hou Y, Nie J, Hou FF, Kahn M, Liu Y (2011) Targeted inhibition of $\beta$-catenin/CBP signaling ameliorates renal interstitial fibrosis. J Am Soc Nephrol 22(9):1642-1653. doi: 10.1681/ASN.2010101079

10. He W, Dai C, Li Y, Zeng G, Monga SP, Liu Y (2009) Wnt/betacatenin signaling promotes renal interstitial fibrosis. J Am Soc Nephrol 20(4):765-776. doi:10.1681/ASN.2008060566

11. He X, Cheng R, Park K, Benyajati S, Moiseyev G, Sun C, Olson LE, Yang Y, Eby BK, Lau K, Ma JX (2017) Pigment epitheliumderived factor, a noninhibitory serine protease inhibitor, is renoprotective by inhibiting the Wnt pathway. Kidney Int 91(3): 642-657. doi:10.1016/j.kint.2016.09.036

12. He X, Semenov M, Tamai K, Zeng X (2004) LDL receptor-related proteins 5 and 6 in Wnt/beta-catenin signaling: arrows point the way. Development 131(8):1663-1677 Review

13. Johnson BG, Ren S, Karaca G, Gomez IG, Fligny C, Smith B, Ergun A, Locke G, Gao B, Hayes S, MacDonnell S, Duffield JS (2017) Connective tissue growth factor domain 4 amplifies fibrotic kidney disease through activation of LDL receptor-related protein 6. J Am Soc Nephrol. doi:10.1681/ASN.2016080826

14. Kawakami T, Ren S, Duffield JS (2013) Wnt signalling in kidney diseases: dual roles in renal injury and repair. J Pathol 229(2):221231. doi:10.1002/path.4121 Review

15. Kohn AD, Moon RT (2005) Wnt and calcium signaling: betacatenin-independent pathways. Cell Calcium 38(3-4):439-446 Review

16. Kuncewitch M, Yang WL, Corbo L, Khader A, Nicastro J, Coppa GF, Wang P (2015) WNT agonist decreases tissue damage and improves renal function after ischemia-reperfusion. Shock 43(3): 268-275. doi:10.1097/SHK.0000000000000293

17. Li Z, Zhou L, Wang Y, Miao J, Hong X, Hou FF, Liu Y (2017) (Pro)renin receptor is an amplifier of $\mathrm{Wnt} / \beta$-catenin signaling in kidney injury and fibrosis. J Am Soc Nephrol. doi:10.1681/ASN. 2016070811

18. Lin SL, Li B, Rao S, Yeo EJ, Hudson TE, Nowlin BT, Pei H, Chen L, Zheng JJ, Carroll TJ, Pollard JW, McMahon AP, Lang RA, Duffield JS (2010) Macrophage Wnt7b is critical for kidney repair and regeneration. Proc Natl Acad Sci U S A 107(9):4194-4199. doi:10.1073/pnas.0912228107

19. Liu M, Shi S, Senthilnathan S, Yu J, Wu E, Bergmann C, Zerres K, Bogdanova N, Coto E, Deltas C, Pierides A, Demetriou K, Devuyst O, Gitomer B, Laakso M, Lumiaho A, Lamnissou K, Magistroni R, Parfrey P, Breuning M, Peters DJ, Torra R, Winearls CG, Torres VE, Harris PC, Paterson AD, Pei Y (2010) Genetic variation of DKK3 may modify renal disease severity in ADPKD. J Am Soc Nephrol 21(9):1510-1520. doi:10.1681/ASN.2010030237

20. Ludwig J, Federico G, Prokosch S, Küblbeck G, Schmitt S, Klevenz A, Gröne HJ, Nitschke L, Arnold B (2015) Dickkopf-3 acts as a modulator of B cell fate and function. J Immunol 194(6): 2624-2634. doi:10.4049/jimmunol.1402160

21. Madan B, Patel MB, Zhang J, Bunte RM, Rudemiller NP, Griffiths R, Virshup DM, Crowley SD (2016) Experimental inhibition of porcupine-mediated Wnt O-acylation attenuates kidney fibrosis. Kidney Int 89(5):1062-1074. doi:10.1016/j.kint.2016.01.017

22. Mao B, Wu W, Davidson G, Marhold J, Li M, Mechler BM, Delius H, Hoppe D, Stannek P, Walter C, Glinka A, Niehrs C (2002 Jun 6) Kremen proteins are Dickkopf receptors that regulate Wnt/betacatenin signalling. Nature 417(6889):664-667

23. Matsuyama M, Nomori A, Nakakuni K, Shimono A, Fukushima M (2014 Nov 7) Secreted Frizzled-related protein 1 (Sfrp1) regulates the progression of renal fibrosis in a mouse model of obstructive nephropathy. J Biol Chem 289(45):31526-31533. doi:10.1074/jbc. M114.584565

24. Meister M, Papatriantafyllou M, Nordström V, Kumar V, Ludwig J, Lui KO, Boyd AS, Popovic ZV, Fleming TH, Moldenhauer G, Nawroth PP, Gröne HJ, Waldmann H, Oelert T, Arnold B (2015) Dickkopf-3, a tissue-derived modulator of local T-cell responses. Front Immunol 6:78. doi:10.3389/fimmu.2015.00078 eCollection 2015

25. Miller RK, McCrea PD (2010) Wnt to build a tube: contributions of Wnt signaling to epithelial tubulogenesis. Dev Dyn 239(1):77-93. doi:10.1002/dvdy.22059 Review

26. Minami Y, Oishi I, Endo M, Nishita M (2010) Ror-family receptor tyrosine kinases in noncanonical Wnt signaling: their implications in developmental morphogenesis and human diseases. Dev Dyn 239(1):1-15. doi:10.1002/dvdy.21991 Review

27. Monaghan AP, Kioschis P, Wu W, Zuniga A, Bock D, Poustka A, Delius H, Niehrs C (1999) Dickkopf genes are co-ordinately expressed in mesodermal lineages. Mech Dev 87(1-2):45-56

28. Nile AH, Mukund S, Stanger K, Wang W, Hannoush RN (2017 Apr 18) Unsaturated fatty acyl recognition by Frizzled receptors mediates dimerization upon Wnt ligand binding. Proc Natl Acad Sci U S A 114(16):4147-4152. doi:10.1073/pnas.1618293114

29. Papatriantafyllou M, Moldenhauer G, Ludwig J, Tafuri A, Garbi N, Hollmann G, Küblbeck G, Klevenz A, Schmitt S, Pougialis G, Niehrs C, Gröne HJ, Hämmerling GJ, Arnold B, Oelert T (2012) Dickkopf-3, an immune modulator in peripheral CD8 T-cell tolerance. Proc Natl Acad Sci U S A 109(5):1631-1636. doi:10.1073/ pnas. 1115980109

30. Ren S, Johnson BG, Kida Y, Ip C, Davidson KC, Lin SL, Kobayashi A, Lang RA, Hadjantonakis AK, Moon RT, Duffield JS (2013) LRP-6 is a coreceptor for multiple fibrogenic signaling pathways in pericytes and myofibroblasts that are inhibited by DKK-1. Proc Natl Acad Sci U S A 110(4):1440-1445. doi:10. 1073/pnas.1211179110

31. Rinkevich Y, Montoro DT, Contreras-Trujillo H, Harari-Steinberg O, Newman AM, Tsai JM, Lim X, Van-Amerongen R, Bowman A, Januszyk M, Pleniceanu O, Nusse R, Longaker MT, Weissman IL, Dekel B (2014 May 22) In vivo clonal analysis reveals lineage- 
restricted progenitor characteristics in mammalian kidney development, maintenance, and regeneration. Cell Rep 7(4):1270-1283. doi:10.1016/j.celrep.2014.04.018

32. Rooney B, O'Donovan H, Gaffney A, Browne M, Faherty N, Curran SP, Sadlier D, Godson C, Brazil DP, Crean J (2011 Feb 4) CTGF/CCN2 activates canonical Wnt signalling in mesangial cells through LRP6: implications for the pathogenesis of diabetic nephropathy. FEBS Lett 585(3):531-538. doi:10.1016/j.febslet. 2011.01.004

33. Satoh M, Nagasu H, Morita Y, Yamaguchi TP, Kanwar YS, Kashihara N (2012 Dec 15) Klotho protects against mouse renal fibrosis by inhibiting Wnt signaling. Am J Physiol Renal Physiol 303(12):F1641-F1651. doi:10.1152/ajprenal.00460.2012

34. Schmidt-Ott KM, Barasch J (2008) WNT/beta-catenin signaling in nephron progenitors and their epithelial progeny. Kidney Int (8): 1004-1008. doi:10.1038/ki.2008.322 Review

35. Semënov MV, Tamai K, Brott BK, Kühl M, Sokol S, He X (2001 Jun 26) Head inducer Dickkopf-1 is a ligand for Wnt coreceptor LRP6. Curr Biol 11(12):951-961

36. Surendran K, McCaul SP, Simon TC (2002) A role for Wnt-4 in renal fibrosis. Am J Physiol Renal Physiol. 282(3):F431-F441

37. Surendran K, Schiavi S, Hruska KA (2005 Aug) Wnt-dependent beta-catenin signaling is activated after unilateral ureteral obstruction, and recombinant secreted Frizzled-related protein 4 alters the progression of renal fibrosis. J Am Soc Nephrol 16(8):2373-2384

38. Surendran K, Simon TC, Liapis H, McGuire JK (2004 Jun) Matrilysin (MMP-7) expression in renal tubular damage: association with Wnt4. Kidney Int 65(6):2212-2222

39. Tamai K, Semenov M, Kato Y, Spokony R, Liu C, Katsuyama Y, Hess F, Saint-Jeannet JP, He X (2000) LDL-receptor-related proteins in Wnt signal transduction. Nature 407(6803):530-535

40. Terada Y, Tanaka H, Okado T, Shimamura H, Inoshita S, Kuwahara M, Sasaki S (2003) Expression and function of the developmental gene Wnt-4 during experimental acute renal failure in rats. J Am Soc Nephrol 14(5):1223-1233
41. Vogetseder A, Palan T, Bacic D, Kaissling B, Le Hir M (2007 Feb) Proximal tubular epithelial cells are generated by division of differentiated cells in the healthy kidney. Am J Physiol Cell Physiol 292(2):C807-C813

42. Wu W, Glinka A, Delius H, Niehrs C (2000) Mutual antagonism between dickkopfl and dickkopf2 regulates Wnt/beta-catenin signalling. Curr Biol 10(24):1611-1614

43. Xue H, Xiao Z, Zhang J, Wen J, Wang Y, Chang Z, Zhao J, Gao X, Du J, Chen YG (2013) Disruption of the Dapper3 gene aggravates ureteral obstruction-mediated renal fibrosis by amplifying $\mathrm{Wnt} / \beta$ catenin signaling. J Biol Chem 288(21):15006-15014. doi:10. 1074/jbc.M113.458448

44. Zhang Z, Iglesias DM, Corsini R, Chu L, Goodyer P (2015) WNT/ $\beta$-catenin signaling is required for integration of $\mathrm{CD} 24+$ renal progenitor cells into glycerol-damaged adult renal tubules. Stem Cells Int 2015:391043. doi:10.1155/2015/391043

45. Zhao SL, Wei SY, Wang YX, Diao TT, Li JS, He YX, Yu J, Jiang XY, Cao Y, Mao XY, Wei QJ, Wang Y, Li B (2016 Sep 7) Wnt4 is a novel biomarker for the early detection of kidney tubular injury after ischemia/reperfusion injury. Sci Rep 6:32610. doi:10.1038/ srep32610

46. Zhou D, Fu H, Zhang L, Zhang K, Min Y, Xiao L, Lin L, Bastacky SI, Liu Y (2017) Tubule-derived Wnts are required for fibroblast activation and kidney fibrosis. J Am Soc Nephrol. doi:10.1681/ ASN.2016080902

47. Zhou D, Li Y, Lin L, Zhou L, Igarashi P, Liu Y (2012) Tubulespecific ablation of endogenous $\beta$-catenin aggravates acute kidney injury in mice. Kidney Int 82(5):537-547. doi:10.1038/ki.2012.173 Erratum in: Kidney Int. 2013 Sep;84(3):626

48. Zhou L, Li Y, Zhou D, Tan RJ, Liu Y (2013 Apr) Loss of Klotho contributes to kidney injury by derepression of Wnt/ $\beta$-catenin signaling. J Am Soc Nephrol 24(5):771-785. doi:10.1681/ASN. 2012080865

49. Zhou D, Tan RJ, Fu H, Liu Y (2016) Wnt/ $\beta$-catenin signaling in kidney injury and repair: a double-edged sword. Lab Investig 96(2): 156-167. doi:10.1038/labinvest.2015.153 Review 